\title{
Teachers Attitude Towards Inclusive Education in Educational Institutions of Pakistan
}

Javaria Khalid, Nooraini Binti Othman

To Link this Article: http://dx.doi.org/10.6007/IJARBSS/v12-i2/12289

DOI:10.6007/IJARBSS/v12-i2/12289

Received: 06 December 2021, Revised: 08 January 2022, Accepted: 28 January 2022

Published Online: 12 February 2022

In-Text Citation: (Khalid \& Othman, 2022)

To Cite this Article: Khalid, J., \& Othman, N. B. (2022). Teachers Attitude Towards Inclusive Education in Educational Institutions of Pakistan. International Journal of Academic Research in Business and Social Sciences, 12(2), 342-353.

\section{Copyright: (c) 2022 The Author(s)}

Published by Human Resource Management Academic Research Society (www.hrmars.com)

This article is published under the Creative Commons Attribution (CC BY 4.0) license. Anyone may reproduce, distribute, translate and create derivative works of this article (for both commercial and non0-commercial purposes), subject to full attribution to the original publication and authors. The full terms of this license may be seen at: http://creativecommons.org/licences/by/4.0/legalcode

\section{Vol. 12, No. 2, 2022, Pg. $342-353$}

Full Terms \& Conditions of access and use can be found at http://hrmars.com/index.php/pages/detail/publication-ethics 


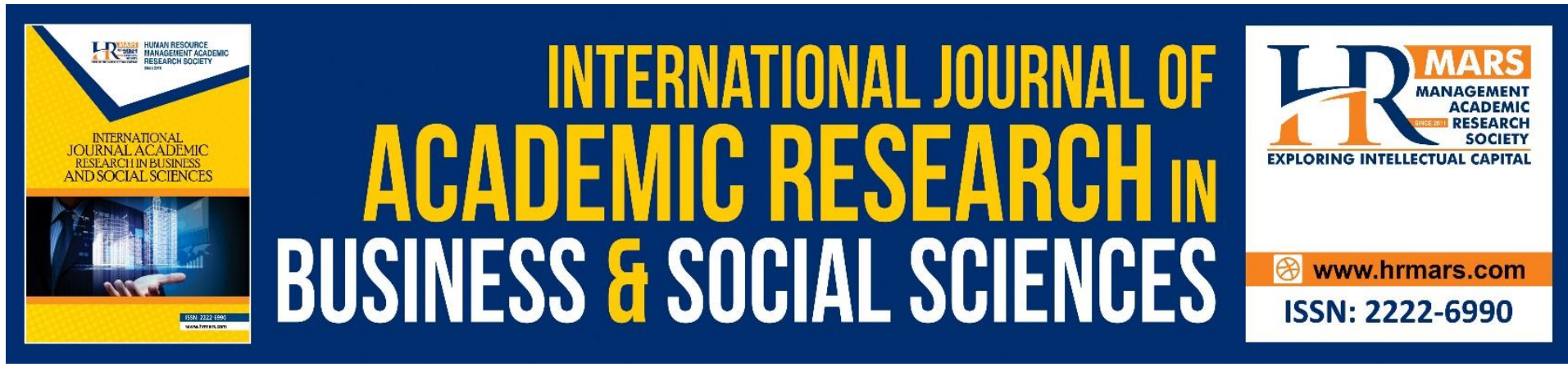

\title{
Teachers Attitude Towards Inclusive Education in Educational Institutions of Pakistan
}

\author{
Javaria Khalid \\ PhD Scholar, Perdana Center, Razak Faculty of Technology and Informatics, UTM, Kuala \\ Lumpur, Malaysia \\ Email: javariaraja@yahoo.com
}

\author{
Assoc. Prof, Director Nooraini Binti Othman \\ Perdana centre of science Technology and innovation policy, Razak Faculty of Technology \\ and informatics, UTM, kualaLampur, Malaysia \\ Email: p-noraini@utm.my
}

\begin{abstract}
The paper provides a useful insight into the dynamics of teacher approaches and attitudes towards inclusive education. It reflects the access and inclusiveness for all educational institutions in Pakistan. The objectives of the research are to analyze the different aspects of teachers' attitudes, and differences between trained and untrained teachers to improve the knowledge towards inclusive education in secondary educational institutions. Using the quantitative research methodology, the survey tool is used for the collection of data. It unfolded that training of the teachers is a compulsory area that needs attention from the higher education experts. The inclusiveness of teachers is possible with the management and better training processes, those are tested in a quantitative setup. The finding of the study incorporated the lapses in un-trained teachers and that is the major reason for reduced access to inclusive education. It is suggested that teacher training, which is a major aspect of gaining access to inclusive education in Pakistani institutions affect on development and progress of teachers' attitudes.
\end{abstract}

Keywords: Teachers, Inclusive Education, Training, Secondary Education

\section{Introduction}

The direction of society has changed now to educate its children. Before this In the 1970s general/regular education has combined with special education and it is known as inclusion While definitions and techniques of inclusion differ, they all support the idea of ensuring that all students have equal access to education (Haug, 2017). Most schools try to arrange all children in one place. The term inclusive education refers to ensuring that education is for all. It's a key strategy to ensure that all (those who have learning difficulties) should get an education with normal children. According to the Eurydice Report and UNESCO documents (2016), In all European countries, inclusive education, or "a school for all," serves as a foundation for assuring equitable opportunities for students with special needs in all parts of 
their lives, including education, professional training, the job, and social life. As a result, an emphasis has been placed on including children with special educational needs in international education programmes and strategies (Savolainen et al., 2017). Children with impairments and with other special educational needs have the right to seek their education in the school with their age group years with the mainstream school without any distinction of capabilities, strengths, economical status, religion, ethnicity or any other distinction.The objective of inclusive education is to ensure that all children can learn. As a result, schooling and teaching must be designed in such a way that all students' special needs are fulfilled and their full potential is attained (Franck and Joshi, 2017).

Communities that work to establish inclusive education systems will serve as catalysts for a more inclusive society (Kokićet al., 2016). An inclusive environment, in contrast to the idea of segregation in education, encourages an educational process that is focused on integration, which requires flexible learning methods that can adapt to each student's different and diverse needs. According to (Loreman et al., 2011; Schmidt \& Vrhovnic, 2015)Acceptance and knowledge of differences and diversity, as well as human rights, social justice, and equal rights concerns, are all aspects of inclusive education. In terms of self-perception as a productive part of society, the participation of students with learning difficulties in schools and educational activities is critical (Monsen et al., 2014). Inclusive education, in which every student is treated equally andTeachers are essential in the development of educational strategies that will assist every child or young person develop to their full potential and contribute to societal sustainability. It is essential to train instructors to address learner differences and provide an inclusive learning environment for all students to have a sustainable future, to which learners in today's various educational institutions should be given the opportunity to contribute.

Teachers from all across the world focus on working actively to educate ongoing and prospective educators to perform within the framework of Inclusive education. The experts at the UNESCO International Conference on Education agreed that a replaced traditional education system into Inclusive education is required to fulfil the needs of all students. They serve as a foundational idea for education that supports long-term continuity and ultimate learning for everyone. The need for university education intraining pre-service and in-service teachers to educate about inclusion was undeniable (Geneva \& Switzerland, 2008). Furthermore, in In2015, Inclusive Education for all was included in the fourth of the 17The Sustainable Development Goals (SDGs) are a set of goals (New York, 2015). Inclusive school infrastructures and teacher training on Inclusive Education should be considered solutions to address exclusions and imbalance, according to the Education 2030 Framework for Action, which gives direction for accomplishing this goal. Teachers who had attended inclusive education training, according to the study, had even more positive attitudes toward the issue. As a result, the authors developed that a basic element of inclusive education has been included in all teacher training education programs (Varcoe \& Boyle, 2014).

Professional experience or seniority, previous experience, level of training, the type of disability of the student, the level of training of the teaching staff working with this category of students, gender, teachers' beliefs about access and success in education and life for people with disabilities, class size, and time to implement in the classroom all influence teachers' attitudes toward inclusive education. While referring to a person's level of 
experience or seniority at work, the authors (Boyle et al., 2013; Forlinet al., 2010; Schmidt \& Vrhovnic, 2015) According to the research, younger teachers have more positive attitude than senior teachers. When previous experience in inclusive education is considered positive, it indicates a more positive attitude and quality work experience.

Inclusive Education is a great challenge for the education system. If it becomes successful, then it provides a new principle, interactive and organizational paradigm. It may become an educational main concern but to do so many changes in the education system. Continuous teachers training programs, social equality, cooperation (school, parents and teachers) new advanced technology according to children's needs and regarding development. Teachers have social, emotional, physical, and academic attitudes toward teaching. The attitudes of pre-service teachers about social concerns and how to connect with students in the class are often well-established as a result of their experiences and background. Pre-service teachers, for example, who had prior experience (as a student or recently) in inclusive classroom settings are more likely to have positive perspectives toward including children with disabilities (Varcoe and Boyle, 2014). The study reflects to analyze the different aspects of teachers' attitudes towards inclusive education. It follows the gap between (teachers' attitude toward inclusive education) trained and untrained teachers. The programs may improve the knowledge and attitude of teachers for higher education access through inclusiveness.

Children with disabilities have been unable to perceive the conduct of their teachers and other classmates. They do not even ask the other students to repeat the lessons that the teachers have taught in class. It was generally accepted that including all students improve their ability and promote their progress towards the meeting and needs of the twenty-first century. Unfortunately, the inclusive attitude has not always been universally adopted. Because disabling students' participation was not acceptable in various socio-cultural contexts, our thinking and belief changed quickly over the previous century and continues to change with the growing social and academic benefits of disabled students (Desalegn and Worku, 2016). The problem that impaired children face during their education within a mainstream school is teachers' attitude towards them, Lack of training and qualification to deal with the needs of special children. For the successful implementation of inclusive education, To work in an inclusive education environment, qualified teachers are sorely needed. So that teachers have to give acceptance and take responsibility for the learning process of children with learning difficulties, other disabilities and parents of the special children need to inform about the purpose and objective including long term and short-term goals in a support program for their special children. Inclusive education requires a great deal of collaboration and sharing of expertise of both regular and special education teachers to achieve the common goals of inclusive education (Zwane and Malale, 2018).

\section{Literature Review}

Many countries have used Inclusive Education to guide one's efforts to make educational practices and policies more inclusive (Ainscow et al.,2019). For at least the last 30 years, it has been seen as a global movement, Inclusive education is one of the most important concerns confronting the education system, both domestically and globally, according to Amor et al (2018) "The process of increasing the educational system's ability to reach out to all learners." It was originally linked to the inclusion of disabled children in the regular educational system (France, 2017). However, other authors pointed out that theory and practice have different 
knowledge and understanding of the concept, making progress in the domain is challenging (Göransson et al., 2014; Magnússon, 2019). As a result of inclusive education research, Göransson and Nilholm identified four meanings of inclusion: (1) inclusion of students with special needs in regular classrooms; (2) supporting the social/academic needs of special students; (3) meeting the social/academic needs of students; and (4) social action. (Krischler et al,.2019) suggest that this conceptual variability which explains the lack of cohesion in the implementation of Inclusive Education and is concerned with training for a better future of learners.

In this study, inclusive education is defined as ensuring that all students, especially those with disabilities, immigrants, and ethnic minorities, have access to learning opportunities, in its broadest sense. However, unless the government provides all of the material, financial inclusion standards, their efforts would be useless if teachers' attitudes toward inclusion remain unchanged (Hadidi and Al Khateeb, 2015). Teachers' concerns and negative attitudes could be effectively addressed in teacher training by delivering well-designed courses regarding inclusion and diversity. According to the study. The main purpose of inclusive education is to break down the barrier of a separate educational system of normal and special children. And special children feel like normal and active members of educational institutions/organizations. And this paper aims to investigate the teachers' attitudes and factors, which influence their attitudes towards inclusive education.In inclusive education the role of a teacher is vital. The teacher should have a practice of inclusive education that relies on their knowledge, understanding, skills and attitude. A teacher's positive attitude towards inclusion can be the key to success for those students who have special needs. Inclusive education needs inclusive teaching training programs, inclusive classrooms and inclusive teaching strategies. The purpose of modern teacher education is to enable teachers for the challenges that come with delivering away in a variety of situations. Teachers/ educators strive to provide programming that incorporates, among other things, theoretical foundations, pedagogy, content, and curriculum expertiseas well as real-life experiences. Preservice teachers' progressive beliefs and attitudes affect their decisions, attitudes and confidence, these are at the root of instructional components. For decades, it has been suggested that pre-service teachers' grounded attitudes and belief system takes priority over other aspects of their initial teacher education curriculum (Krischler \& Pit-ten Cate, 2019).

Furthermore, research shows that teachers who are enthusiastic about inclusive education are more likely to modify their teaching techniques to handle a wide range of educational needs (Swain et al., 2012). To address these concerns, teacher-preoperational programmes must create and these programs designed to help future teachers understand the environmental, social, and cultural contexts of learning, attitudes, and teaching, and be able to put these understandings into a profession in inclusive classrooms serving increasingly diverse students(Killoran et al., 2014). Furthermore, studies have shown that early education programs will provide Positive and progressive attitudes toward inclusive education are based upon the foundation(Johnson \& Howell, 200; Jung, 2007; Kim, 2011; Mc Hatton \& Parker, 2013; Swain et al., 2012).). While other research shows that Teachers who have a positive opinion toward inclusive education are more likely to get pre-service training, which addresses teachers' concerns and better prepares them to handle issues in the classroom. (Harvey et al., 2010). However, researches regarding teacher education and how it affects 
teachers' attitude on inclusive education are inadequate which has shown conflicting results (Lautenbach \& Heyder, 2019).

Teachers' attitudes are important when it relates to promoting, It can support or impede the development of inclusive policies, proper inclusion of students with special needs(Schmidt and Ksenja, 2015).In Bhutan, there is very little research on teachers' attitudes towards inclusion (UNICEF 2014). LhamDorji (2012) in a monograph cited and UNICEF, (2014) revealed that people of Bhutan are usually supportive of people with disabilities, despite a recent media report claiming negative views toward those people who have disabilities and it spread at all levels in the society of Bhutan (Kharka, 2016). Both studies must be considered with suspicion because they need factual evidence to support their statements. Teacher-related factors include gender, age, teaching experience, grade level taught, experience with children having disabilities, and personality traits. According to the International Journal of Inclusive Education (Cambridge et al., 2014; Schmidt \& Ksenja, 2015)above is a brief overview that how many teacher-related variables influence teachers' attitudes towards inclusion.

\section{Methodology}

The survey approach was used to collect data for descriptive research .A well-designed questionnaire was the source of gathering data. The study's respondents were private school teachers who taught at schools in Islamabad and Rawalpindi. A random sampling method was used to select a sample from the population. All the participants are teaching in Rawalpindi and Islamabad schools. The total number of teachers is 80 which take from private schools as a sample. A developed questionnaire, which is based on existing literature to measure the variables. A questionnaire has consisted of 22 items. The instrument measured teachers' attitudes, perceptions and inclusion towards inclusive education.

Each item was contained on five options, Female teachers are more supportive of including children with special needs in regular classes than male teachers (Boyle \& Topping et al., 2013). In terms of teaching experience, young teachers with fewer years of experience have a higher chance of being selected than older teachers with more years of experience. In contrast, a recent study of Slovenia revealed that young teachers who have less experience were more concerned about inclusion (Schmidt and Ksenja, 2015). Teachers with higher qualifications in India were more likely to be positive towards inclusion. In Bangladesh, on the other hand, Sharma et al (2012) Teachers with bachelor's degrees less than had more positive attitudes towards inclusion than those having master's degrees, according to the research. The objective of this study is to provide policy direction to curriculum planners, textbook developers, teacher trainers, and reviewers to upgrade the way to design curriculum. On the other side, this study may be useful to policymakers in revealing that government policies do not serve education to special students. Those students need a specially designed curriculum and instructional courses. And those parents who are anxious about their children's ability to obtain specialized academic support from qualified teachers. It is possibly beneficial for students with special educational needs in this challenging world either they can deal with a variety of life's challenges. In every culture, there are multiple challenges for the teachers. These challenges are for those students who have learning difficulties, parent's attitude, poor cooperation of school management had affected them. There is not only a need to make this generation aware of risks but also teachers' training and time to time conferences can improve these problems. This study may be overcome the challenges of society. For teachers 
who are uncomfortable and unprepared with inclusion, this research would be beneficial for them to develop confidence and success in those students. It would be a noteworthy effort to place those students in a regular class and surely this act guide special education this time and next time.

\section{Data Analysis and Discussion}

A number of statistical analysis tests were carried out to achieve the objectives of the study and test the research questions. These tests are done with the findings.

Qualification

Table:1Distribution of respondents according to their qualification

\begin{tabular}{|c|c|c|c|}
\hline Groups & N & Mean & SD \\
\hline B.A & 33 & 71.3333 & 9.07148 \\
\hline M.A & 43 & 66.2558 & 11.18905 \\
\hline M.Phil & 4 & 74.7500 & 22.69178 \\
\hline Total & 80 & 68.7750 & 11.28904 \\
\hline
\end{tabular}

The above table shows the summary test scores among the three groups. Teachers' attitude group B. A's mean score of 33 out of 80 , with an SD of 9.07148, a mean of 71.3333, and a second M. A group consisted of 43 persons out of 80, with an SD of 11.18905 and a mean of 66.2558. Then there is athird M. Phil group got just 4 out of 80 points, with SD of 22.69178 and a mean of 74.7750. The table's result reveals that the three groups' understanding of the subject is not equal.

Table: 2

\begin{tabular}{|c|c|c|c|c|c|}
\hline $\begin{array}{c}\text { Source of } \\
\text { Variation }\end{array}$ & Sum of square & DF & Mean Square & F & P \\
\hline $\begin{array}{c}\text { Between } \\
\text { groups }\end{array}$ & 631.681 & 2 & 315.840 & 2.577 & .083 \\
\hline $\begin{array}{c}\text { Within } \\
\text { groups }\end{array}$ & 9436.269 & 77 & 122.549 & & \\
\hline Total & 10067.950 & 79 & & & \\
\hline
\end{tabular}

The significant difference in mean pretest scores among the three groups can be seen in the table above. The results show that the pretest mean scores of the given three groups are significantly different Because F-value of 2.577 is greater than p-value at the.083 level.

Professional Qualification:

Table:3Distribution of professional qualification

\begin{tabular}{|c|c|c|c|}
\hline Groups & N & Mean & Std. Dev \\
\hline Nil & 56 & 66.3750 & 11.07916 \\
\hline B. Ed & 18 & 75.0000 & 10.08785 \\
\hline M.Ed. & 5 & 69.8000 & 8.13634 \\
\hline Dip-Training & 1 & 86.0000 & - \\
\hline Total & 80 & 68.7750 & 11.28904 \\
\hline
\end{tabular}

In the summary test scores, the comparison between four groups is shown in the above table. Teachers' attitude group got a 56 out of 80 on the professional qualification scale, with SD of 11.07916, the mean was 66.3750 and the second being B. Ed 18 out of 80 with SD of 10.08785 , 
the mean was 75.0000, as well as the third M.Ed group, had SD of 8.13634 with a mean of 69.8000. The fourth group of teaching diploma holders had only 1 out of 80 and SD=0, with a mean of 86.0000 . The table shows that the knowledge of four professional trained groups on the problem was not equal.

Table:4

\begin{tabular}{|l|l|l|l|l|l|}
\hline $\begin{array}{l}\text { Source of } \\
\text { variation }\end{array}$ & Sum of squares & Df & Mean square & $\mathrm{F}$ & $\mathrm{P}$ \\
\hline $\begin{array}{l}\text { Between } \\
\text { groups }\end{array}$ & 1322.025 & 3 & 440.675 & 3.829 & .013 \\
\hline Within groups & 8745.925 & 76 & 115.078 & & \\
\hline Total & 10067.950 & 79 & & & \\
\hline
\end{tabular}

The significant difference in mean pretest scores between the four groups is shown in the above table. The table's findings show that the mean pretest scores of the three groups differed significantly. Because of F-value 3.829 is greater than p-value at the .531 level.

Table:5 Distribution of respondents according to teaching experience

\begin{tabular}{|c|c|c|c|}
\hline Group & N & Mean & Std .Devi \\
\hline 0 (Nill) & 8 & 73.3750 & 12.78322 \\
\hline $1-5$ & 49 & 67.2857 & 9.82980 \\
\hline $6-10$ & 16 & 69.5625 & 14.87714 \\
\hline $11-15$ & 4 & 70.0000 & 13.44123 \\
\hline 15 Above & 3 & 75.0000 & 2.64575 \\
\hline & 80 & 68.7750 & 11.28904 \\
\hline
\end{tabular}

The above table shows the summary test scores among four comparison groups. Teachers attitude group had a mean score of 56 out of $80, S D=11.07916$, Mean was 66.3750, B. Ed had a mean score of 18 out of $80, S D=10.08785$, Mean was 75.0000 , and M.Ed had a mean score of 5 out of $80, S D=8.13634$, Mean was 69.8000 . The fourth group of teaching diploma holders had just 1 out of 80 and $S D=0$, with a mean of 86.0000 . The table shows that the knowledge of four professional trained groups on the issue was not equal.

The purpose of the study is to measure teachers' abilities in the context of inclusive education, as well as their conditions, merits, and concerns of those students who have a special need in the classrooms, to conduct psychometric testing. The questionnaire's validity was determined through the participation of inclusive education experts in the item design process. The following conclusions were drawn based on the study's findings. The study reports some barriers were determined towards the teachers' attitude to be a successful part of inclusion. There is a difference between trained and untrained teachers' attitudes that's why Teachers training programs for inclusive education had a deep effect on trained or untrained teachers' attitudes. To enhance teachers' attitudes towards inclusive education special teaching training programs affected their attitude. The division of teaching qualifications, gender status, and experience shows that there are differences between each group.

The findings are significant because they pertain to educators' assessments of what preservice teachers are learning, as well as professional learning facilitators' assessments of what in-service teachers are capable of learning. As we endeavour to provide high-quality teacher education and in-service training, a careful investigation of beliefs and attitudes toward 
inclusion becomes an important part of the planning and delivery process. Differentiation among learners in the class has been found that is not to benefited learning. Differentiation in teacher education and professional development would naturally start with a study of how teachers' experiences and beliefs affect what they take away from their training. This work provides a comprehensive understanding of how they handle work with students that seem to have a range of problems. If teachers have a positive attitude towards inclusion, they will be more willing to adapt teaching techniques to accommodate a variety of student learning needs. As the researcher attempted to define these mindsets in our study, research also reveals effective techniques that help teachers in the establishment of positive attitudes and thinking towards education that would give benefit the objective of complete inclusion and even more. This study gives motivation especially to the teachers in Pakistan, that the movement for inclusive education got its promotion on the assumption that students with learning difficulties are motivated and willing to move towards regular class and passionate in this contact for the meeting of their unique needs. However, some misconceptions and negative attitudes started to be reflected in some cases. Research outcomes in the area of inclusive education of these children suggest that attitude plays a key role in the successful implementation of any course. The successful social interaction and communication among these students can win the attention of those students in favour of the inclusive setup. The attitude that has a negative impact place a limitation on the students towards the success of inclusive education.

\section{Conclusion}

The study reports some barriers were determined towards the teacher's attitude to be a successful part of inclusion. There is a difference between trained and untrained teachers' attitudes. Teachers training programs for inclusive education had a profound effect on trained or untrained teachers' attitudes. To enhance teachers' attitudes towards inclusive education special teaching training programs affected their attitude. The goal of this report was to construct a questionnaire to assess teacher qualifications in the context of inclusive education, as well as to investigate the conditions, benefits, and consequences of including students with special educational needs in the classroom, and to conduct psychometric testing. The questionnaire's validity is measured through the inclusion of inclusive education experts in the item design process. There are differences between and within groups of each class, as shown by the division of teaching qualifications, gender, and experience. They are significant in terms of teacher educators' show to evaluate them and what their pre-service teachers are learning and how professional development facilitators assess what in-service teachers will learn, even if they are not absolutes.

The significance of this paper is to put an effort to provide quality education to the teachers through initial training programs, the study of beliefs and attitudes linked to inclusion and it becomes an important component of planning and delivery. It has been shown that promoting students without differentiation within the classroom supports learning. Differentiation in teacher education and professional learning would start with a review of how teachers' experiences and ideas are formed which affect what they take away from their education and training programs. This research gives us an understanding of how the teachers approach working with students who have many difficulties. The study was intended to analyze Teachers' perception towards inclusive education in terms of real practice of inclusive education. It gives benefits to those students who have to learn difficulty in receiving education through inclusive education. It is estimated that the findings of this research will 
be a significant contribution in the field of inclusive education for the students who have to learn difficulty in Pakistan. based on findings it can be concluded that education administration, teachers, professionals and social workers should make arrangements for uplifting the mindset of people and teachers towards awareness of inclusive education.

\section{Policy Implications}

The policy implications provide that government need to give attention and promote inclusive education. They support and cooperate with teachers because teachers are the nation builder and teachers can make students a better citizen. In many countries including Pakistan, our teachers are facing many problems. They are not provided with basic facilities in their professional life. Hence it is further recommended that: In School principals may give the training to develop a helpful relationship with the teacher, in this way it may guide the teacher where they are lacking. Policymakers can make educational policies according to inclusive students. Special policies may be made for the inclusive education system. Special teacher training programs may arrange for teachers. Motivate teachers by educational trainers towards inclusion. Pre-service and in-service teaching training programs can be arranged to enhance teachers learning. Special teaching training programs improve the teaching quality towards inclusion education systems, which may lead to achieving the target of inclusive education's knowledge and attitude towards change. Teachers' attitudes should always be positive towards education. Every teacher professionally qualifies before teaching. Those factors should be overcome which influenced inclusive education. Remove those aspects in which inclusionary teaching practices lead the teachers towards a negative attitude. Policymakers should design special teaching programs to improve or increase teachers' interest in inclusive education. Special assessment systems should be introduced. Curriculum makers should develop a special curriculum for an inclusive education system. It may lead to achieving the target of inclusive education. In addition, the findings of the study aim to add more in the present education show understanding of inclusive education of inclusive students with this intention that it can be used to modify the current policies of inclusive education for students with special needs in Pakistan. It is hoped that the findings of this research can be used to help policymakers because this research will provide them framework about the perception of inclusive students. Also be helpful for the teachers, administration as well as policymakers while finalizing teaching methodologies, syllabus and curriculum as well as extra-curricular activities while formulating and implementing within inclusive classrooms. Many factors continue affecting and regulating the development of inclusive education in a country. Limited awareness about the disability, negative attitudes towards persons with disabilities and communication gaps among different persons are the major barrier impeding inclusive education. Hence, with great concern, the factors that might affect teachers' attitudes, teachers' role and training in an integrated setting and challenges of inclusive education should be addressed. Mainly, students' and teachers' attitude toward inclusion is a key problem for the implementation of the program.

\section{References}

Ahmmed, M., Sharma, U., \& Deppeler, J. (2012). Variables affecting teachers' attitudes towards inclusive education in Bangladesh. Journal of research in special educational needs, 12(3), 132-140.

AlMahdi, O., \& Bukamal, H. (2019). Pre-service teachers' attitudes toward inclusive education during their studies in Bahrain Teachers College. SAGE Open, 9(3), 2158244019865772. 
Amor, A. M., Hagiwara, M., Shogren, K. A., Thompson, J. R., Verdugo, M. Á., Burke, K. M., \& Aguayo, V. (2019). International perspectives and trends in research on inclusive education: A systematic review. International Journal of Inclusive Education, 23(12), 1277-1295.

Batarelo Kokić, I., Kurz, T. L., \& Novosel, V. (2016). Student teachers' perceptions of an inclusive future. Paper presented at the European Conference on Information Literacy.

Boyle, C., Topping, K., \& Jindal-Snape, D. (2013). Teachers' attitudes towards inclusion in high schools. Teachers and teaching, 19(5), 527-542.

Brel, P. (2016). Structural Indicators on Early Childhood Education and Care in Europe. Education and Training.

Cambridge-Johnson, J., Hunter-Johnson, Y., \& Newton, N. G. (2014). Breaking the Silence of Mainstream Teachers' Attitude towards Inclusive Education in the Bahamas: High School Teachers' Perceptions. Qualitative Report, 19(42).

Clipa, O., Mata, L., \& Lazar, I. (2020). Measuring In-Service Teachers' Attitudes Towards Inclusive Education. International Journal of Disability, Development and Education, 67(2), 135-150.

Cretu, D. M., \& Morandau, F. (2020). Initial teacher education for inclusive education: A bibliometric analysis of educational research. Sustainability, 12(12), 4923.

Cretu, D. M., \& Morandau, F. (2020). Initial teacher education for inclusive education: A bibliometric analysis of educational research. Sustainability, 12(12), 4923.

Desalegn, D., \& Worku, A. (2016). Review of challenges of hearing-impaired students in integrated class in public schools in Ethiopia: A Review Article. Journal of Medicine, physiology and Biophysics, 22, 74-78.

Dorji, R., Bailey, J., Paterson, D., Graham, L., \& Miller, J. (2021). Bhutanese teachers' attitudes towards inclusive education. International Journal of Inclusive Education, 25(5), 545564.

Franck, B., \& Joshi, D. K. (2017). Including students with disabilities in education for all: Lessons from Ethiopia. International Journal of Inclusive Education, 21(4), 347-360.

Göransson, K., \& Nilholm, C. (2014). Conceptual diversities and empirical shortcomings-a critical analysis of research on inclusive education. European journal of special needs education, 29(3), 265-280.

Hadidi, M. S., \& Al Khateeb, J. M. (2015). Special education in Arab countries: Current challenges. International Journal of Disability, Development and Education, 62(5), 518530.

Harvey, M. W., Yssel, N., Bauserman, A. D., \& Merbler, J. B. (2010). Preservice teacher preparation for inclusion: An exploration of higher education teacher-training institutions. Remedial and Special Education, 31(1), 24-33.

Harvey, M. W., Yssel, N., Bauserman, A. D., \& Merbler, J. B. (2010). Preservice teacher preparation for inclusion: An exploration of higher education teacher-training institutions. Remedial and Special Education, 31(1), 24-33.

Hassanein, E. E., Alshaboul, Y. M., \& Ibrahim, S. (2021). The impact of teacher preparation on preservice teachers' attitudes toward inclusive education in Qatar. Heliyon, 7(9), e07925.

Haug, P. (2017). Understanding inclusive education: ideals and reality. Scandinavian journal of disability research, 19(3), 206-217.

Ismailos, L., Gallagher, T., Bennett, S., \& Li, X. (2019). Pre-service and in-service teachers' attitudes and self-efficacy beliefs with regards to inclusive education. International 
Journal of Inclusive Education, 1-17.

Khan, A. M., Sami, A., \& Salahuddin, A. (2021). Attitude of Hearing Impaired Students towards Inclusive Education in Pakistan. Journal of Inclusive Education, 5(1), 1-14.

Killoran, I., Woronko, D., \& Zaretsky, H. (2014). Exploring preservice teachers' attitudes towards inclusion. International Journal of Inclusive Education, 18(4), 427-442.

Kim, J. R. (2011). Influence of teacher preparation programmes on preservice teachers' attitudes toward inclusion. International Journal of Inclusive Education, 15(3), 355-377.

Krischler, M., Powell, J. J., \& Pit-Ten Cate, I. M. (2019). What is meant by inclusion? On the effects of different definitions on attitudes toward inclusive education. European journal of special needs education, 34(5), 632-648.

Lautenbach, F., \& Heyder, A. (2019). Changing attitudes to inclusion in preservice teacher education: a systematic review. Educational Research, 61(2), 231-253.

Monsen, J. J., Ewing, D. L., \& Kwoka, M. (2014). Teachers' attitudes towards inclusion, perceived adequacy of support and classroom learning environment. Learning environments research, 17(1), 113-126.

Nations, U. (2015). Transforming our world: the 2030 agenda for sustainable development. New York: United Nations, Department of Economic and Social Affairs.

Savolainen, H., Engelbrecht, P., Nel, M., \& Malinen, O.-P. (2012). Understanding teachers' attitudes and self-efficacy in inclusive education: Implications for pre-service and inservice teacher education. European journal of special needs education, 27(1), 51-68.

Schmidt, M., \& Vrhovnik, K. (2015). Attitudes of teachers towards the inclusion of children with special needs in primary and secondary schools. Hrvatska revija za rehabilitacijska istraživanja, 51(2), 16-30.

Schmidt, M., \& Vrhovnik, K. (2015). Attitudes of teachers towards the inclusion of children with special needs in primary and secondary schools. Hrvatska revija za rehabilitacijska istraživanja, 51(2), 16-30.

Singh, J. P. (2010). United Nations Educational, Scientific, and Cultural Organization (UNESCO): creating norms for a complex world: Routledge.

Swain, K. D., Nordness, P. D., \& Leader-Janssen, E. M. (2012). Changes in preservice teacher attitudes toward inclusion. Preventing School Failure: Alternative Education for Children and Youth, 56(2), 75-81.

UNICEF. (2014). Meeting the educational needs of children with disabilities in south Asia: A gap analysis covering Bhutan and the Maldives: Kathmandu: UNICEF Regional Office of South Asia (ROSA).

Varcoe, L., \& Boyle, C. (2014). Pre-service primary teachers' attitudes towards inclusive education. Educational Psychology, 34(3), 323-337.

Varcoe, L., \& Boyle, C. (2014). Pre-service primary teachers' attitudes towards inclusive education. Educational Psychology, 34(3), 323-337.

Zwane, S. L., \& Malale, M. M. (2018). Investigating barriers teachers face in the implementation of inclusive education in high schools in Gege branch, Swaziland. African journal of Disability, 7(1), 1-12. 